\title{
Penggunaan Media Permainan (Teka Teki Dadu) untuk Meningkatkan Aktivitas dan Hasil Belajar Menulis Siswa Kelas IX A SMP Negeri 3 Bintan
}

\author{
Rahmawati Scorpiana* \\ SMP Negeri 3 Bintan, Bintan, Indonesia \\ Pengiriman: 20/10/2019; Diterima: 03/10/2020; Publikasi: 20/11/2020
}

DOI: 10.31629/kiprah.v8i2.1633

\begin{abstract}
Abstrak
Penelitian ini bertujuan untuk mendeskripsikan penggunaan media permainan Teka Teki Dadu dalam meningkatkan aktivitas dan hasil belajar menulis siswa kelas IX A SMP Negeri 3 Bintan Tahun Pelajaran 2018/2019. Tujuan pembelajaran menulis yang ingin dicapai yaitu siswa mampu mengungkapkan informasi dalam bentuk iklan baris, resensi, dan karangan. Subjek penelitian adalah siswa kelas IX A berjumlah 32 siswa. Instrumen dalam penelitian ini terdiri atas lembar penilaian tertulis (penilaian proyek), lembar observasi, dan angket. Teknik pengumpulan data menggunakan analisis deskriptif. Hasil penelitian menunjukkan adanya peningkatan persentase rata-rata keaktifan siswa dari $63,54 \%$ pada siklus pertama menjadi $77,08 \%$ pada siklus kedua. Penggunaan media permainan (Teka Teki Dadu) juga meningkatkan hasil belajar menulis siswa. Hal ini terlihat adanya peningkatan dari siklus pertama sampai siklus kedua. Peningkatan jumlah siswa yang tuntas sebelum tindakan (prasiklus) hanya 50,00\% (16 siswa), pada siklus pertama mencapai 65,63\% (22 siswa) dan pada siklus kedua ketuntasan meningkat menjadi 81,25\% (26 siswa). Penggunaan media permainan (Teka Teki Dadu) dalam pembelajaran ternyata mendapat tanggapan positif, 97,50\% siswa setuju dengan penggunaan media ini karena dapat memudahkan mereka memahami konsep-konsep dan materi pelajaran, membuat suasana belajar menjadi menyenangkan, memacu mereka untuk aktif, dan membiasakan siswa untuk bekerja sama.
\end{abstract}

Kata kunci: aktivitas; hasil belajar; media; menulis

\begin{abstract}
This study aims to describe the buse of Dice Puzzle Game media to improve writing activities and learning outcomes of grade IX A students of SMP Negeri 3 Bintan 2018/2019 Academic Year. The research subjects were 32 students of Class IX A. The instruments in this study consisted of a written assessment sheet (project appraisal), an observation sheet, and a questionnaire. Data collection techniques using descriptive analysis. The results showed an increase in the average percentage of student activity from $63,54 \%$ in the first cycle increased to $77,08 \%$ in the second cycle. The use of game media (Dice Puzzle) also improves student writing learning outcomes, this is seen by a significant increase from the first cycle to the second cycle. The increase in the number of students who completed it before the action (prasiklus) was only $50,00 \%$ ( 16 students), in the first cycle it reached $65,63 \%$ (22 students) and in the second cycle completeness rose to $81,25 \%$ (26 students). The use of game media (Dice Puzzle) in learning turned out to get a positive response 97,50\% of students agreed with the use of this media because it can facilitate them to understand concepts and subject matter, make the learning atmosphere enjoyable, encourage them to be active, familiarize students to cooperate.
\end{abstract}

Keywords: activities; learning outcome; media; writing

*Email Korespondensi: rahmascorpiana@gmail.com 


\section{PENDAHULUAN}

Keberhasilan siswa di sekolah dalam proses pembelajaran sangat ditentukan oleh keterampilan menulisnya. Oleh karena itu, pembelajaran menulis memiliki kedudukan yang tinggi dibanding keterampilan berbahasa lainnya, sehingga harus lebih dikuasai oleh siswa. Kenyataan yang penulis temui di lapangan bahwa hasil belajar Bahasa Indonesia (Menulis) di kelas IX A SMP Negeri 3 Bintan masih rendah. Hal ini ditunjukkan dengan rendahnya persentase siswa yang mencapai nilai Kriteria Ketuntasan Minimal. Pada pokok bahasan Menulis, setelah dilakukan penilaian terhadap hasil belajar kepada 32 siswa kelas IX A ternyata 16 siswa atau sekitar $50 \%$ tidak mampu memperoleh nilai 78 sebagai batas ketuntasan minimal. Muncul dugaan bahwa pembelajaran Bahasa Indonesia (Menulis) di kelas IX A SMP Negeri 3 Bintan masih dilakukan dengan menggunakan metode ceramah (konvensional) dan hanya menggunakan media cetak saja (buku pegangan siswa dan contoh-contoh teks), padahal guru bisa berinovasi dengan cara memvariasikan pembelajaran dengan menggunakan media yang lebih bersifat interaktif salah satunya adalah dengan menggunakan media permainan (games) seperti TTS, Permainan Ular Tangga, dan lainlain.

Untuk meningkatkan hasil belajar dan minat siswa dalam mata pelajaran Bahasa Indonesia khususnya Kompetensi Dasar menulis (Iklan Baris dan Meresensi Buku Pengetahuan), penulis berusaha mengadopsi media permainan ini yang sudah ada dengan teknik ATM (amati, tiru, dan modifikasi) sehingga akhirnya terciptalah media permainan yang penulis beri nama "Teka Teki Dadu". Pemilihan media permainan ini dengan pertimbangan jika diterapkan media ini dalam pembelajaran maka aktivitas dan hasil belajar menulis siswa kelas IX A SMP Negeri 3 Bintan akan meningkat.

Wicaksono et al. (2018) mengatakan syarat mutlak terjadinya pembelajaran di kelas apabila terjalin komunikasi yang baik dan menyambung antara guru dan siswa. Untuk itu diperlukan suatu alat bantu belajar yaitu dengan menggunakan media permainan. Dalam penelitian ini, penulis menggunakan media permainan teka teki dadu.

Hasil penelitian Santi Pradila Sandi (2018), pembelajaran kooperatif dengan strategi permainan teka teki silang dapat meningkatkan aktivitas guru, aktivitas siswa dan hasil belajar IPS siswa kelas IX.4 Sekolah Menengah Pertama Negeri 1 Mempura Kecamatan Mempura Kabupaten Siak tahun pelajaran 2015 - 2016. Menurut Setia \& Jakarta (2018), penggunaan media permainan (kartu kata) dapat meningkatkan dan menstimulus siswa agar dapat berpikir dan menambah kosa kata untuk dapat meningkatkan kemampuan menulis dan meningkatkan semangat siswa dalam belajar. Berdasarkan eksplorasi penulis, ditemukan tulisan yang berkaitan dengan penelitian ini yang dilakukan oleh Abdul Muin Tahun 2018 dengan judul "Teka-Teki Dadu Kata untuk Meningkatkan Aktivitas dan Hasil Belajar Materi Membaca, Menulis, dan Berhitung”. Hasil Penelitian menunjukkan bahwa media pembelajaran Teka-teki Dadu Kata dapat meningkatan aktivitas dan hasil belajar materi membaca, menulis, dan berhitung pada peserta didik kelas I SDN Glawan.

Adapun perbedaan penelitian ini dari penelitian sebelumnya yaitu, 1) penelitian yang penulis lakukan ini ditujukan untuk siswa SMP; 2) bertujuan untuk mengungkapkan informasi dalam bentuk iklan baris, resensi, dan karangan (kemampuan menulis); dan 3) merupakan alat bantu yang memudahkan guru karena untuk membuatnya sangat mudah dan tidak memerlukan biaya yang mahal, tetapi guru dapat memanfaatkan bahan daur ulang sehingga ramah lingkungan. Sebaliknya, pada penelitian sebelumnya yang dilakukan oleh Abdul Muin tahun 2018 tujuan penggunaan media Teka Teki Dadu Kata hanya untuk memperkenalkan huruf dan angka dalam pelajaran menulis, membaca, dan berhitung 
untuk siswa SD. Persamaan penelitian ini dengan penelitian sebelumnya setelah digunakan media permainan (Teka Teki Dadu) adalah sama-sama dapat meningkatan hasil dan aktivitas belajar siswa dalam proses pembelajaran di kelas.

Hal ini jelas menandakan jika media pembelajaran memiliki peranan penting terhadap proses pembelajaran baik bagi siswa maupun bagi guru sebagai alat bantu dalam menyampaikan pembelajaran di kelas. Kata media berasal dari Bahasa Latin "medius" yang berarti pengantar atau perantara. Menurut Mahnun (2012), media adalah alat yang dapat menyampaikan pesan atau informasi. Arsyad (2015) mendefinisikan media pembelajaran sebagai alat untuk mempermudah pemahaman siswa terhadap materi pelajaran yang disampaikan oleh guru. Palahudin (2014) mengatakan media belajar yang baik akan mempengaruhi aktivitas dan hasil belajar siswa. Pemilihan media menjadi tolak ukur penting dalam menentukan berhasil tidaknya suatu pembelajaran di kelas.

Tolak ukur media yang baik, yaitu: (1) media yang baik harus mempunyai tujuan penggunaan yang jelas; (2) media yang digunakan guru harus sesuai atau tepat sasaran dengan peserta didik yang menggunakan media pembelajaran tersebut; (3) karakteristik media; (4) media tersebut dapat digunakan sesuai dengan waktu yang tersedia dalam proses pembelajaran; (5) biaya untuk membuatnya terjangkau, dan (6) bahan untuk membuatnya mudah didapat.

Menurut Aminoto \& Patoni (2015), aktivitas belajar adalah segala bentuk tindakan siswa dalam proses belajar mengajar di kelas baik berupa kegiatan menulis, membaca, mendengarkan, maupun aktivitas lainnya yang positif dan dapat mempengaruhi siswa untuk senang dalam mengikuti pembelajaran yang diberikan oleh guru.

Dari uraian tersebut dapat disimpulkan hasil belajar merupakan perubahan perilaku siswa yang berupa kemampuan-kemampuan yang meliputi aspek kognitif, afektif dan psikomotor yang diperoleh dari proses belajar siswa sesuai dengan tujuan pembelajaran.

Menurut Tarigan (Sugiarti, 2018), "Menulis adalah suatu kegiatan yang produktif dan ekspresif". Dalam kegiatan menulis ini, penulis haruslah terampil memanfaatkan struktur bahasa, dan kosa kata. Keterampilan menulis ini tidak akan datang secara otomatis, melainkan harus melalui latihan dan praktik yang banyak dan teratur.

$$
\text { Menurut Sukarto (2010:3), }
$$

pembelajaran menulis memiliki 4 tujuan yaitu menginformasikan segala sesuatu, membujuk, mendidik, dan menghibur. Menulis dalam pembahasan penelitian ini berhubungan dengan kemampuan siswa dalam menulis iklan baris dan menulis resensi buku pengetahuan populer yang menjadi topik bahasan pembelajaran di kelas IX untuk semester ganjil, yaitu pada KD 4.1 dan 4.2. Aspek penilaian kemampuan menulis yang akan dinilai dalam penelitian ini adalah 1) kelengkapan isi tulisan; 2) ketepatan pemilihan kata-kata; 3) ketepatan penggunaan bahasa; 4) kerapian tulisan (EYD).

Berdasarkan latar belakang permasalahan yang dipaparkan, penulis melakukan penelitian yang berjudul "Penggunaan Media Permainan (Teka Teki Dadu) untuk Meningkatkan Aktivitas dan hasil belajar Menulis Siswa Kelas IX A SMP Negeri 3 Bintan" dengan tujuan untuk mendeskripsikan manfaat media permainan Teka Teki Dadu terhadap peningkatkan aktivitas dan hasil belajar menulis siswa kelas IX A SMP Negeri 3 Bintan.

\section{METODE PENELITIAN}

\section{Rancangan Penelitian}

Penelitian ini dilakukan pada semester ganjil tahun pelajaran 2018/2019. Dimulai dengan penyusunan proposal Penelitian Tindakan Kelas pada bulan Agustus 2018, pelaksanaan penelitian siklus 1 dilakukan pada minggu kedua di bulan September 2018, siklus II dilaksanakan pada minggu keempat di bulan September 2018. Penyusunan laporan PTK dilakukan pada bulan November 2018 sampai dengan bulan Desember 2018 (tepatnya pada 
minggu kedua). Lokasi penelitian bertempat di SMP Negeri 3 Bintan beralamat di Jalan Nusantara Km 18 Kijang, Kelurahan Gunung Lengkuas, Kecamatan Bintan Timur, Kabupaten Bintan, Kepulauan Riau.

\section{Subjek Penelitian}

Subjek penelitian dalam penelitian ini adalah seluruh siswa kelas IX.A berjumlah 32 siswa terdiri dari 17 siswa laki-laki dan 15 siswa perempuan.

\section{Teknik Pengumpulan Data}

Teknik pengumpulan data dilakukan dengan menggunakan:

a. Penilaian Proyek digunakan untuk mengumpulkan hasil pembelajaran menulis (KD 4.1 dan KD 4.2) pada siklus I dan siklus II. Indikator kinerja adalah $75 \%$ atau lebih siswa menyelesaikan tugas dan $75 \%$ siswa memperoleh nilai $\geq 78$.

b. Observasi digunakan untuk mengumpulkan lembar observasi. Indikator kinerja adalah $75 \%$ siswa dapat terlibat aktif dalam proses pembelajaran menulis dengan penggunaan media permainan (Teka Teki Dadu) selama proses pembelajaran berlangsung.

c. Angket digunakan untuk mengungkap tanggapan balik siswa terhadap aktivitas tindakan penelitian.

\section{Teknik Analisis Data}

Dalam menganalisis data, penulis menggunakan analisis deskriptif gambaran data secara umum tentang hasil belajar dan keaktifan siswa dalam memahami konsepkonsep pada Standar Kompetensi 4 (Menulis). Mengungkapkan informasi dalam bentuk iklan baris, resensi, dan karangan (KD 4.1 dan KD 4.2). Analisis data tentang ketercapaian kompetensi dasar (hasil belajar) menulis dilakukan dengan melihat hasil belajar siswa secara individual.

Peningkatan hasil belajar menulis dilihat dengan membandingkan skor hasil belajar siswa sebelum tindakan dengan skor dasar siswa yang diperoleh setelah tindakan.
Hasil menulis siswa dikatakan meningkat apabila skor yang diperoleh setelah menggunakan media permainan dalam pembelajaran lebih baik dari skor dasar sebelum diberi tindakan. Data penelitian dianalisis dengan menggunakan analisis deskriptif dengan tujuan untuk menentukan tingkat ketercapaian pada masing-masing variabel.

a. Menentukan tingkat ketercapaian hasil belajar:

$$
\mathrm{PTP}=\frac{S D S}{S M} \times 100
$$

Keterangan:

PTP $=$ Persentase Tingkat Penguasaan

SDS = Skor yang diperoleh siswa

$\mathrm{SM}=$ Skor maksimum dari tes

b. Persentase ketuntasan belajar siswa secara klasikal dihitung dengan menggunakan rumus (Purwanto, 1992)

$\mathrm{P}=\frac{\text { banyak siswa yang tuntas belajar }}{\text { jumlah keseluruhan siswa }} \times 100 \%$

Ketuntasan belajar siswa secara klasikal dinyatakan tercapai apabila sekurangkurangnya $75 \%$ dari jumlah siswa dalam kelas tersebut telah memenuhi kriteria tuntas secara individu yaitu 78 .

c. Menentukan persentase aktivitas siswa dalam proses pembelajaran

Persentase Aktivitas $=\frac{\text { Aktivitas yang diperoleh }}{\text { Aktivitas Naksimal }} \times 100 \%$

Aktivitas siswa dikatakan baik apabila terjadi peningkatan pada setiap siklus.

\section{HASIL DAN PEMBAHASAN Hasil Penelitian}

Berdasarkan data awal (prasiklus) dari penilaian proyek pada pokok bahasan menulis hanya terdapat 16 peserta didik dari $32(50 \%)$ yang berhasil tuntas dengan KKM 78. Dari data awal tersebut, peneliti mulai melakukan penelitian tindakan kelas dengan hasil sebagai berikut :

\section{Siklus Pertama}

\section{a. Perencanaan}

Kegiatan yang dilakukan pada siklus ini adalah mengenai pokok bahasan menulis yaitu menulis iklan baris (KD 4.1) ada pun 
rangkaian kegiatan yang dilakukan adalah : 1) menyusun rencana pelaksanaan pembelajaran untuk 1 kali pertemuan, yang akan dilaksanakan pada Hari Selasa, tanggal 11 September 2018 dengan SK "Mengungkapkan informasi dalam bentuk iklan baris, resensi, dan karangan" untuk KD 4.1 tentang Menulis Iklan Baris; 2) menyiapkan bahan ajar dalam bentuk media permainan Teka Teki Dadu; 3) menyiapkan instrumen penilaian proyek untuk mengukur hasil belajar menulis siswa. 5) membuat lembar observasi untuk mengamati perilaku siswa selama pelaksanaan tindakan; 6) menetapkan langkah-langkah kerja yang dilakukan siswa, yaitu: a) guru memastikan semua siswa siap untuk menerima pelajaran sesuai dengan $\mathrm{KD}$; b) guru meminta siswa untuk mengamati materi pelajaran yang akan dibahas dalam proses pembelajaran selama 5 menit (mengamati contoh teks iklan baris).

Pada perencanaan siklus pertama dan kedua ditambahkan sebuah permainan pada pembelajaran. Menurut (Widiastuti, 2012) pada umumnya peserta didik suka belajar apabila diselingi dengan permainan yang mengedukasi. Dalam hal ini permainan yang dilakukan dengan menggunakan media adalah Teka Teki Dadu.

Aturan cara penggunaan media Teka Teki Dadu ini mula-mula guru memberi contoh dengan menyusun beberapa dadu menjadi kata. Selanjutnya, peserta didik dibimbing oleh guru untuk membuat kata baru dengan menggunakan salah satu huruf baik secara mendatar maupun menurun. Guru membagikan 5 lembar kertas warna kepada seluruh siswa, kemudian guru menempelkan media permainan (Teka Teki Dadu) di papan tulis. Sementara itu, siswa di bawah bimbingan guru menggunakan media secara bergantian untuk menemukan jawaban yang ada pada pertanyaan dengan bantuan dadu dan kertas warna yang dibagikan guru. Selanjutnya, guru memeriksa jawaban yang ditempelkan siswa pada papan teka teki dan guru memberikan penilaian dan penghargaan terhadap jawaban pertanyaan yang ada dalam papan teka teki berupa pujian kepada siswa. Siswa membuat simpulan hasil belajar dengan bimbingan guru, kemudian siswa membuat tugas proyek yang diberikan guru. Selanjutnya membuat simpulan sementara hasil siklus pertama.

\section{Pelaksanaan Tindakan}

Pelaksanaan penelitian siklus pertama dilakukan sebanyak satu kali pertemuan, untuk $1 \mathrm{KD} 4.1$ (Menulis Iklan Baris). Pertemuan pertama dilaksanakan pada hari Selasa, tanggal 11 September 2018 jam ke-7 dan 8. Kegiatan pembelajaran dimulai dengan guru (penulis) meminta ketua kelas untuk memimpin doa. Selanjutnya, menyebutkan KD yang akan dicapai siswa dalam proses pembelajaran dan menyebutkan tujuan pembelajaran hari ini. Sesudah itu, pada kegiatan pembuka guru melakukan apersepsi dan motivasi.

Pada kegiatan eksplorasi, guru memulai dengan memfasilitasi interaksi antara siswa dengan siswa, siswa dengan guru, lingkungan, dan sumber belajar lainnya. Guru memastikan semua siswa siap untuk menerima pelajaran dan memerhatikan media permainan (Teka Teki Dadu) tentang menulis iklan baris. Selanjutnya, guru meminta siswa untuk membaca dan memahami contoh teks iklan baris yang ada pada buku pegangan siswa selama 5-10 menit sebelum memulai menggunakan media permainan Teka Teki Dadu tersebut. Guru menempelkan media permainan (Teka Teki Dadu) tentang cara menulis iklan baris.

Pada saat kegiatan elaborasi, siswa dibimbing guru menggunakan media tersebut secara bergantian untuk menemukan jawaban tentang cara menyusun iklan baris yang ada pada pertanyaan dengan bantuan dadu dan kertas warna yang dibagikan guru. Sesudah itu, peserta didik menempelkan jawaban dari tiap-tiap pertanyaan yang ada pada papan teka teki dengan menggunakan kertas warna-warni (kertas origami). Jawaban yang ada pada papan teka teki merupakan kata-kata yang harus siswa pahami atau kata acuan dalam menyusun iklan baris yang baik dan benar.

Pada kegiatan konfirmasi, guru bersama siswa merangkum apa yang telah 
siswa kerjakan mengenai KD 4.1. Sebelum mengakhiri proses pembelajaran pada kegiatan penutup, guru memberikan tugas individu dalam bentuk penugasan proyek menulis teks iklan baris yang harus dikerjakan siswa dan menetapkan waktu pengumpulan tugas tersebut secara bersama-sama. Tugas ini diberikan untuk mengetahui hasil belajar siswa terhadap pemahaman materi yang telah disampaikan guru melalui penggunaan media permainan Teka Teki Dadu.

\section{Pengamatan}

Hasil pengamatan terhadap perilaku (keaktifan siswa) selama pelaksanaan pembelajaran adalah sebagai berikut.

Pada siklus pertama, ditemukan 12 siswa $\quad(37,50 \%)$ yang aktif dalam mendengarkan penjelasan guru dalam proses pembelajaran tentang bagaimana cara menulis iklan baris yang disajikan guru melalui media permainan Teka Teki Dadut. Siswa terlihat antusias mendengarkan penjelasan yang diberikan guru dari awal sampai akhir tentang bagaimana cara memainkan media Teka Teki Dadu yang berhubungan dengan materi dalam KD 4.1.

Untuk menjawab pertanyaan dalam permainan tersebut, mereka harus bermain dengan cara melemparkan dadu. Nomor yang tertera di dadu yang mereka lemparkan itulah nantinya yang boleh mereka isi dengan cara menempelkan pada nomor pertanyaan yang mereka pilih. Siswa mengisi dengan menuliskan huruf sesuai dengan dadu yang mereka peroleh setelah dilemparkan di depan kelas. Setelah selesai menempelkan huruf perhuruf sesuai dengan angka yang ada pada mata dadu peserta didik melemparkan permainan ke siswa lain yang menurut mereka layak untuk melanjutkan permainan sampai menghasilkan sebuah kata yang sesuai dengan materi cara menyusun iklan baris. Jika pada saat melemparkan dadu muncul angka enam, siswa tidak diperbolehkan bermain. Akan tetapi, mereka memilih siswa yang lain untuk melanjutkan permainan sampai seluruh siswa dapat bermain secara bergantian sehingga siswa ditantang untuk lebih konsentrasi dalam menyimak setiap pertanyaan yang ada dalam permainan tersebut.

Terdapat 28 siswa $(87,50 \%)$ mau menjawab pertanyaan yang terdapat dalam media Teka Teki Dadu tersebut. Saat menjawab terlihat siswa sangat ceria dan tidak tertekan dalam mengikuti proses pembelajaran yang dilakukan guru di dalam kelas. Hal ini penulis amati dari cara mereka bermain. Mereka tidak merasa takut dan terbebani, tetapi mereka sangat senang dan antusias untuk menjawab pertanyaan yang ada dalam permainan Teka Teki Dadu tersebut. Sebanyak $21(65,63 \%)$ siswa sudah mulai berpartisipasi (kolaborasi) dengan teman dalam bentuk saling membantu untuk menemukan jawaban dalam pertanyaan yang berhubungan dengan teks iklan baris yang dibuat penulis (guru). Pemahaman terhadap pokok bahasan menulis teks iklan baris sudah baik.

\section{Refleksi}

Hasil penilaian terhadap tugas proyek yang dibuat peserta didik untuk mengukur hasil belajar pada siklus pertama tersebut diperoleh nilai terendah 55 dan tertinggi 95 dengan nilai rata-rata 76,00 . Jumlah siswa tuntas sebanyak 22 siswa $(68,75 \%)$. Siswa yang belum mencapai ketuntasan minimal ada 10 orang $(31,25 \%)$ dari 32 siswa.

Berdasarkan hasil pengamatan pada siklus pertama dapat direfleksikan sebagai berikut. Pertama, pada awal siklus pertama pertemuan pertama belum semua siswa siap dengan penerapan media permainan Teka Teki Dadu dalam proses pembelajaran karena mereka terbiasa dengan pembelajaran yang berpusat pada guru. Kedua, interaksi dengan teman dalam belajar belum maksimal karena mereka masih belum terbiasa dengan dengan penerapan media permainan Teka Teki Dadu dalam proses pembelajaran menulis iklan baris. Ketiga, walaupun hasil belajar siswa sudah mengalami peningkatan jika dibandingkan dengan nilai ketuntasan hasil belajar menulis di awal/prasiklus dari 32 siswa hanya 16 siswa (50\%) siswa yang mencapai ketuntasan minimal menjadi 22 siswa 
$(68,75 \%)$ mencapai nilai ketuntasan minimal 78. Jadi, penelitian ini dilanjutkan dengan siklus kedua karena ketuntasan siswa dalam pembelajaran belum mencapai lebih dari atau sama dengan $75 \%$.

\section{Rencana Perbaikan}

Berdasarkan refleksi siklus pertama, peneliti merencanakan perbaikan untuk siklus kedua dengan menitikberatkan pada proses pembelajaran, yaitu: 1) memberi dorongan kepada siswa untuk aktif berpartisipasi pada saat berlangsungnya pembelajaran dengan media permainan Teka Teki Dadu tersebut; 2) menambah lebih banyak pertanyaan untuk ditampilkan dalam media permainan Teka Teki Dadu tersebut sesuai dengan materi yang ada dalam KD (menulis).

\section{Siklus Kedua}

\section{Perencanaan}

Berdasarkan kelemahan-kelemahan yang terdapat pada siklus pertama, maka kegiatan yang dilakukan peneliti adalah: 1) membuat rencana pelaksanaan pembelajaran untuk tindakan pada siklus kedua. Siklus kedua akan dilaksanakan pada hari Selasa tanggal 25 September 2018 jam ke-7 dan 8 dengan KD 4.2 (Meresensi Buku Pengetahuan); 2) membuat format angket untuk mengetahui tanggapan siswa terhadap penerapan media permainan Teka Teki Dadu dalam pembelajaran.

\section{Pelaksanaan tindakan}

Pelaksa naan penelitian siklus kedua dilakukan sebanyak satu kali pertemuan. Dilakukan pada hari Selasa, tanggal 25 September 2018. Kali ini dengan KD 4.2 Meresensi Buku Pengetahuan.

Pada kegiatan eksplorasi, guru memulai dengan memfasilitasi interaksi antara siswa dengan siswa, siswa dengan guru, lingkungan, dan sumber belajar lainnya. Guru memastikan semua siswa siap untuk menerima pelajaran dan memperhatikan media permainan (Teka Teki Dadu) tentang Meresensi Buku Pengetahuan. Sesudah itu, guru meminta siswa untuk membaca dan memahami contoh teks resensi buku pengetahuan yang ada pada buku pegangan siswa selama 5 menit sebelum memulai menggunakan media permainan Teka Teki Dadu. Guru menempelkan media permainan (Teka Teki Dadu) tentang cara meresensi buku pengetahuan.

Pada saat kegiatan elaborasi, siswa di bawah bimbingan guru menggunakan media tersebut secara bergantian untuk menemukan jawaban tentang cara meresensi buku pengetahuan yang ada pada pertanyaan dengan bantuan dadu dan kertas warna yang dibagikan guru. Selanjutnya, siswa menempelkan jawaban dari tiap-tiap pertanyaan yang ada pada papan teka teki dengan menggunakan kertas warna-warni (kertas origami). Jawaban yang ada pada papan teka teki merupakan kata-kata yang harus siswa pahami dalam meresensi buku pengetahuan atau kata acuan/kunci untuk meresensi buku pengetahuan yang baik dan benar.

Pada kegiatan konfirmasi, guru bersama siswa merangkum apa yang telah siswa kerjakan melalui media permainan Teka Teki Dadu. Sebelum mengakhiri proses pembelajaran pada kegiatan penutup tidak lupa guru memberikan tugas individu dalam bentuk penugasan proyek menulis resensi buku pengetahuan yang harus dikerjakan siswa dan menetapkan waktu pengumpulan tugas tersebut secara bersama-sama. Tugas ini diberikan untuk mengetahui hasil belajar siswa.

\section{Pengamatan}

Selama pelaksanaan pembelajaran siklus kedua terjadi peningkatan keaktifan siswa dalam proses belajar mengajar. Sembilan belas siswa $(59,38 \%)$ mampu mendengarkan dengan baik dan bersungguhsungguh dalam mengikuti jalannya proses pembelajaran yang disajikan guru dalam media permainan Teka Teki Dadu. Sebanyak 29 siswa $(90,61 \%)$ sudah mulai mau menjawab pertanyaan yang ada dalam permainan Teka Teki Dadu tersebut dengan baik, dan 26 siswa $(81,25 \%)$ mau berpartisipasi dalam kelompok/permainan. Hasil pengamatan terhadap keaktifan siswa mulai dari siklus pertama hingga siklus kedua 
dinyatakan dalam tabel dan grafik berikut

Tabel 1. Persentase Keaktifan Siswa dalam Pembelajaran dengan Media Permainan Teka Teki Dadu Siklus I dan Siklus II

\begin{tabular}{llcc}
\hline No. & \multicolumn{1}{c}{$\begin{array}{c}\text { Aspek yang } \\
\text { Dinilai }\end{array}$} & \multicolumn{1}{c}{$\begin{array}{c}\text { Siklus } \\
\text { Pertatama }\end{array}$} & $\begin{array}{c}\text { Siklus } \\
\text { Kedua }\end{array}$ \\
\cline { 2 - 4 } & & $\begin{array}{c}\text { Persenta- } \\
\text { se }(\%)\end{array}$ & $\begin{array}{c}\text { Persenta- } \\
\text { se (\%) }\end{array}$ \\
\hline 1. & $\begin{array}{l}\text { Ketekunan } \\
\text { memperhatikan } \\
\text { jalannya per- } \\
\text { mainan (meng- } \\
\text { amati) }\end{array}$ & 59,38 \\
Kesungguhan \\
menjawab per- \\
tanyaan \\
Kemampuan ber- \\
partisipasi dalam \\
permainan (kola- \\
borasi)
\end{tabular}

Dari tabel 1 dapat diketahui persentase keaktifan siswa dalam pembelajaran dengan media permainan Teka Teki Dadu untuk aspek ketekunan memerhatikan jalannya permainan (mengamati) pada siklus pertama dari 32 siswa kelas IX.A SMP Negeri 3 Bintan sebanyak 12 siswa $(37,50 \%)$ sudah bisa aktif mengikuti jalannya permainan, sedangkan pada siklus kedua menjadi 19 siswa $(59,35 \%)$ berarti terjadi peningkatan keaktifan sebesar $21,85 \%$. Aspek kesungguhan menjawab pertanyaan pada siklus pertama sebanyak 28 siswa $(87,50 \%)$ pada siklus kedua menjadi 29 siswa $(90,61 \%)$ terjadi peningkatan sebesar $3,11 \%$. Sementara itu, aspek kemampuan berpartisipasi dalam permainan (kolaborasi) pada siklus pertama terdapat 21 siswa yang ikut berpartisipasi dalam kelompoknya $(65,63 \%)$ tetapi pada siklus kedua terdapat 26 siswa $(81,25 \%)$ berarti terjadi peningkatan aktifitas siswa sebesar $15,62 \%$. Jadi, dapat disimpulkan penggunaan media permainan Teka Teki Dadu dalam pembelajaran menulis dapat meningkatan keaktifan siswa dalam menerima pelajaran.

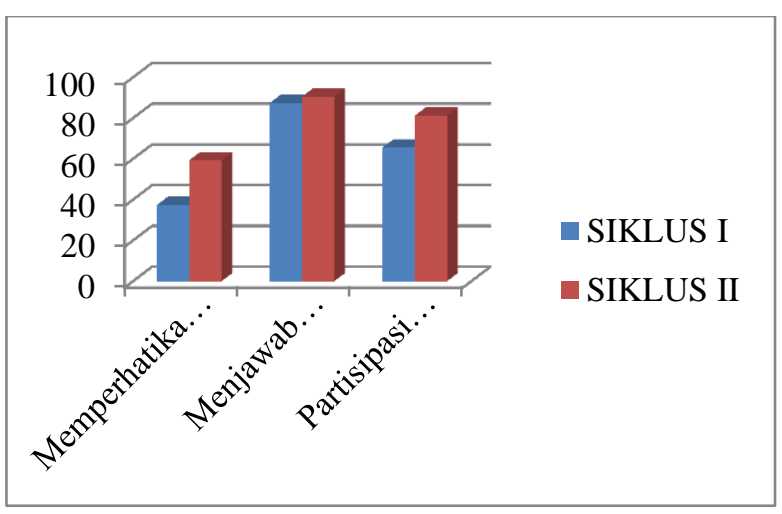

Gambar 1. Grafik Persentase Keaktifan Siswa dalam Pembelajaran Siklus I dan II

Dari gambar 1 dapat diketahui grafik persentase keaktifan siswa dalam pembelajaran dengan media permainan Teka Teki Dadu untuk aspek ketekunan memperhatikan jalannya permainan (mengamati) pada siklus pertama 37,50\%, sedangkan pada siklus kedua menjadi 59,35\%. Aspek kesungguhan menjawab pertanyaan pada siklus pertama $87,50 \%$ pada siklus kedua menjadi 90,61\%. Sementara itu, aspek kemampuan berpartisipasi dalam permainan (kolaborasi) pada siklus pertama 65,63\%, tetapi di siklus kedua menjadi 81,25\%. Akhirnya dapat disimpulkan dengan penggunaan media permainan Teka Teki Dadu dalam pembelajaran menulis dapat meningkatan keaktifan siswa dalam menerima pelajaran yang diberikan guru.

Berdasarkan tabel 1 dan gambar 1 terdapat peningkatan keaktifan siswa, baik dalam hal kemampuan memerhatikan (mengamati), kemampuan menjawab pertanyaan yang diberikan guru dalam media permainan, maupun kemampuan berpartisipasi dalam kelompok (kolaborasi). Persentase ratarata keaktifan siswa pada siklus pertama baru mencapai $63,54 \%$ meningkat menjadi $77.08 \%$ pada siklus kedua. Pemahaman terhadap konsep dan materi pelajaran pada pokok bahasan meresensi buku pengetahuan (KD 4.2) sudah baik.

\section{Refleksi}

Dari hasil penilaian tugas proyek pada siklus kedua diperoleh nilai terendah 60 , nilai tertinggi 98 dan nilai rata-rata 79,25. 
Tabel 2. Sebaran Nilai Penugasan Proyek Siswa Siklus I dan Siklus II

\begin{tabular}{cccccc}
\hline No. & $\begin{array}{c}\text { Rentang } \\
\text { Nilai }\end{array}$ & \multicolumn{2}{c}{ Siklus Pertama } & \multicolumn{2}{c}{ Siklus Kedua } \\
\cline { 3 - 6 } & & $\begin{array}{c}\text { Fre- } \\
\text { kuen- }\end{array}$ & $(\%)$ & $\begin{array}{c}\text { Fre- } \\
\text { Kuen- }\end{array}$ & $(\%)$ \\
& & si & & si \\
\hline 1. & $<78$ & 10 & 31,25 & 6 & 18,75 \\
2. & $78-85$ & 17 & 53,13 & 22 & 68,75 \\
3. & $86-93$ & 4 & 12,50 & 1 & 3,12 \\
4. & $94-100$ & 1 & 3,12 & 3 & 9,38 \\
\multicolumn{2}{c}{ Jumlah } & 32 & 100 & 32 & 100 \\
\hline
\end{tabular}

Dari Tabel 2 dapat diketahui sebaran nilai penugasan proyek siswa untuk siklus pertama dan kedua. Pada siklus pertama siswa yang mendapat nilai di bawah KKM atau tidak tuntas $<78$ sebanyak 10 siswa $(31,25 \%)$ terdiri dari 3 siswa memperoleh nilai 55, nilai 60 sebanyak 2 siswa, nilai 70 sebanyak 5 siswa. Akan tetapi, pada siklus kedua siswa yang memperoleh nilai di bawah KKM atau tidak tuntas menjadi 6 siswa $(18,75 \%)$ dengan rincian 1 siswa memperoleh nilai 60 dan 5 siswa memperoleh nilai 70 . Siswa yang mendapat nilai dengan rentang $78-85$ sebanyak 17 siswa dengan rincian siswa yang mendapat nilai 78 sebanyak 5 siswa, nilai 80 sebanyak 12 siswa, dan nilai 82 sebanyak I siswa.

Akan tetapi, pada siklus kedua terjadi peningkatan sebanyak 22 siswa $(68,75 \%)$ dengan perincian 7 siswa mendapat nilai 78 , 14 siswa mendapat nilai 80 , dan nilai 82 sebanyak 1 siswa. Siswa yang memperoleh nilai 86-93 pada siklus pertama sebanyak 4 siswa $(12,50 \%)$ terdiri atas 4 siswa yang memperoleh nilai 90, sedangkan pada siklus kedua hanya ada 1 siswa $(3,12 \%)$ dengan nilai 90. Ada pun siswa yang mendapat nilai 94 sampai 100 pada siklus pertama sebanyak 1 siswa $(3,12 \%)$ dengan nilai 95 . Namun, pada siklus kedua terjadi perubahan menjadi 3 siswa $(9,38 \%)$ dengan perincian 2 siswa memperoleh nilai 95 dan 1 siswa dengan nilai 98 .

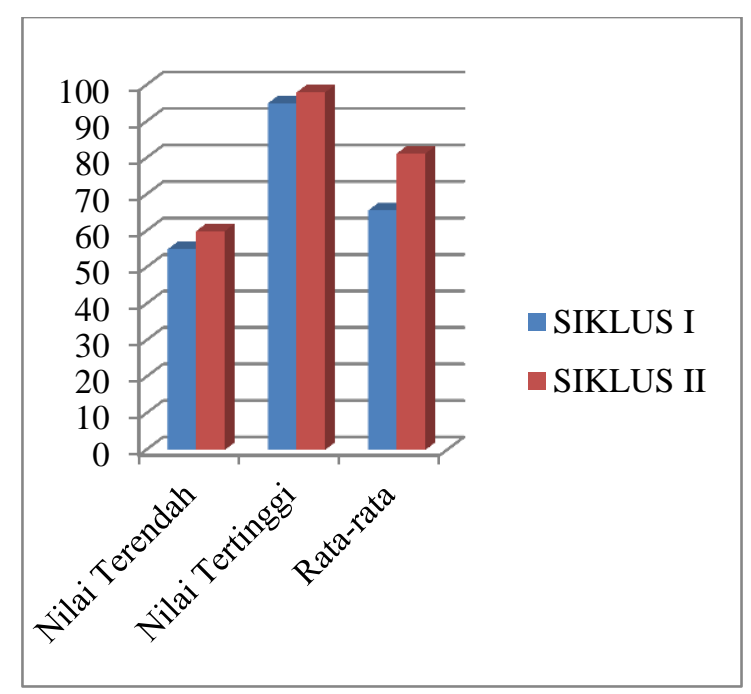

Gambar 2. Grafik Nilai Penugasan Proyek Siklus I dan Siklus II

Gambar 2 berisi grafik nilai tertinggi dan terendah siswa kelas IX.A SMP Negeri 3 Bintan berdasarkan penilaian tugas proyek yang diberikan guru. Siklus pertama nilai terendah 55, nilai tertinggi 95, dan rata-rata kelas 65,63. Sementara itu, siklus kedua terjadi peningkatan hasil belajar siswa dengan nilai terendah 60 , nilai tertinggi 98 , dan nilai ratarata kelas 81,25.

Berdasarkan tabel 2 dan gambar 2 terdapat peningkatan pada nilai penugasan proyek yaitu dari rata-rata nilai 65,63 pada siklus pertama menjadi 81,25 pada siklus kedua. Jumlah siswa yang mencapai batas ketuntasan minimal $65,63 \%$ pada siklus pertama menjadi $81,25 \%$ pada siklus kedua. Persentase rata-rata keaktifan siswa pada siklus pertama $63,54 \%$ meningkat menjadi $77,08 \%$ pada siklus kedua.

Untuk mengetahui tanggapan siswa terhadap penerapan media pembelajaran Teka Teki Dadu dalam pembelajaran, peneliti menggunakan angket. Hasil angket menggambarkan bahwa $97,5 \%$ siswa menyatakan setuju apabila media pembelajaran Teka Teki Dadu dapat membuat suasana belajar menjadi menyenangkan, mudah memahami materi pelajaran, membuat terbiasa untuk bekerja sama, memacu untuk belajar aktif, dan sangat setuju untuk dilanjutkan penggunaannya. Adapun 2,5\% 
siswa menyatakan tidak setuju apabila guru menggunakan teknik tersebut dalam proses pembelajaran, pembelajaran menjadi menyenangkan dan mudah dipahami.

\section{Pembahasan}

Penelitian tindakan kelas adalah penelitian yang digunakan untuk memperbaiki proses pembelajaran di kelas. Hasil yang diharapkan adalah adanya peningkatan, baik aktivitas maupun hasil belajar siswa. Berdasarkan hasil penelitian yang telah dilakukan terdapat peningkatan hasil belajar menulis siswa dimana hal ini terbukti dengan adanya peningkatan ketuntasan rata-rata kelas IX.A pada siklus pertama yaitu $65,63 \%$ terjadi peningkatan ketuntasan rata-rata kelas pada siklus kedua menjadi $81,25 \%$. Peningkatan ketuntasan hasil belajar pada siklus kedua ini wajar dan membuktikan bahwa penggunaan media pembelajaran Teka Teki Dadu ini efektif untuk mengajarkan kemampuan menulis Iklan Baris dan resensi Buku Pengetahuan popular untuk siswa kelas IX. Hal ini berhubungan dengan penelitian sebelumnya yang dilakukan oleh Santi Pradila Sandi (2018) pembelajaran kooperatif dengan strategi permainan teka teki silang dapat meningkatkan aktivitas siswa dan hasil belajar IPS siswa kelas IX.4 Sekolah Menengah Pertama Negeri 1 Mempura Kecamatan Mempura Kabupaten Siak tahun pelajaran 2015-2016. Dari hasil penelitian tersebut dapat diketahui terjadi peningkatan ketuntasan rata-rata hasil belajar siswa pada siklus pertama $34,37 \%$, siklus kedua tuntas $59,57 \%$, dan siklus ketiga 93,75\%. Hal ini jelas membuktikan bahwa penggunaan media pembelajaran efektif untuk meningkatkan aktivitas dan hasil belajar siswa.

Begitu juga dengan keaktifan siswa dalam mengikuti pembelajaran pun mengalami peningkatan hal ini terlihat pada siklus pertama Persentase rata-rata keaktifan siswa pada siklus pertama $63,54 \%$ meningkat menjadi $77.08 \%$ pada siklus kedua. Peningkatan ini wajar karena media yang digunakan dalam penelitian ini (Teka Teki Dadu) menarik sehingga dapat memotivasi siswa untuk belajar.

Hal ini pun sesuai dengan hasil penelitian sebelumnya Setia \& Jakarta (2018), yang menyatakan penggunaan media permainan (kartu kata) dapat meningkatkan dan menstimulus siswa agar dapat berpikir dan menambah kosa kata untuk dapat meningkatkan kemampuan menulis dan meningkatkan semangat siswa dalam belajar. Pemilihan media pembelajaran yang tepat dapat menarik perhatian siswa sehingga mereka aktif mengikuti pembelajaran (Yuniati dkk., 2011).

\section{KESIMPULAN}

Berdasarkan hasil analisis deskriptif "Penggunaan Media Permainan Teka Teki Dadu untuk Meningkatkan Aktivitas dan Hasil Belajar Menulis Siswa Kelas IX A SMP Negeri 3 Bintan", maka penulis menyimpulkan bahwa aktivitas dan hasil belajar menulis untuk KD iklan baris dan meresensi buku pengetahuan terjadi peningkatan pada setiap siklus baik siklus pertama maupun siklus kedua. Dengan demikian, penggunaan media permainan Teka Teki Dadu baik digunakan untuk meningkatkan aktivitas dan hasil belajar menulis. Penerapan media permainan ini dapat mengubah fenomena cara mengajar yang verbalisme dan berpusat pada guru menjadi pembelajaran yang aktif, inovatif, kreatif, menyenangkan dan berpusat pada siswa sebagai subjek belajar.

\section{UCAPAN TERIMA KASIH}

Terima kasih penulis sampaikan kepada keluarga, kepala sekolah, siswa kelas IX A, serta rekan guru mata pelajaran Bahasa Indonesia di SMP Negeri 3 Bintan karena kerjasama, motivasi, dan dukungannya penelitian ini bisa terselesaikan.

\section{REFERENSI}

Abdul, M. (2018). Teka-teki dadu kata Untuk Meningkatkan Aktivitas dan Hasil Belajar Materi Membaca, Menulis, dan Berhitung. Kongres Bahasa Indonesia. Aminoto, T., \& Patoni, H. (2015). Penerapan 
Media E-learning Berbasis Tekhnologi Untuk Meningkatkan Hasil Belajar Materi Usaha dan Energi di Kelas IX SMAN 10 Kota Jambi. MATEC Web of Conferences.

Arsyad, A., \& Sulfemi, W. B. (2018). Metode Role Playing Berbantu Media Audio Visual Pendidikan dalam Meningkatkan Belajar IPS. Jurnal PIPSI (Jurnal Pendidikan IPS Indonesia). https://doi.org/10.26737/jpipsi.v3i2.1012

Falahudin, I. (2014). Pemanfaatan Media dalam Pembelajaran. 4, 104-117.

Mahnun, N. (2012). Media Pembelajaran (Kajian terhadap Langkah-langkah Pemilihan Media dan Implementasinya dalam Pembelajaran). An-Nida', 37(1), 27-35.

Syarifuddin, Ahmad. (2011). Penerapan Model Pembelajaran Cooperative Belajar dan Faktor-Faktor yang Mempengaruhinya. Jurnal Ta'dib Vol. XVI No.1.

Purwanto, M. N. (1992). Prinsip-Prinsip dan Teknik Evaluasi Pengajaran.Bandung: PT Remaja Rosdakarya.

Santi Pradila Sandi. (2018). Penggunaan Media Teka Teki Silang dalam Meningkatkan Hasil Belajar Siswa Kelas IX.4 Pada Pembelajaran IPS di SMPN 1
Mempura Kecamatan Mempura Kabupaten Siak. Jurnal Pelangi, 11. https://doi.org/10.22202/jp.2017.v10.i2.2 845

Setia, G. P., \& Jakarta, U. N. (2018). Penggunaan Media Kartu Kata Dalam. 320-326.

Sugiarti, E. (2018). Peningkatan Keterampilan Menulis Narasi melalui Media Jejaring Sosial Facebook. 87-101. https://doi.org/10.22236/JOLLAR

Wicaksono, H., Roekhan, \& Hasanah, M. (2018). Pengembangan Media Permainan Imajinasi dalam Pembelajaran Menulis Puisi bagi Siswa Kelas X. Jurnal Pendidikan, 3(2), 223-228.

Widiastuti, N. I. (2012). Membangun Game Edukasi Sejarah Walisongo. Komputa: Jurnal Ilmiah Komputer Dan Informatika.

https://doi.org/10.34010/komputa.v1i2.60

Yuniati, N., Purnama, B. E., \& Nurgoho, G. K. (2011). Pembuatan Media Pembelajaran Interaktif Ilmu Pengetahuan Alam Pada Sekolah Dasar Negeri Kroyo 1 Sragen. Jurnal Speed - Sentra Penelitian Engineering Dan Edukasi, 3(4), 25-29. http://speed.web.id/ejournal/index.php/sp eed/article/view/247 